\title{
The Antioxidant and Cytotoxic Effects of Cosmos caudatus Ethanolic Extract on Cervical Cancer
}

\author{
Betty Nurhayati ${ }^{1}$, Ira Gustira Rahayu ${ }^{1}$, Sonny Feisal Rinaldi ${ }^{1}$, Wawan Sofwan Zaini², \\ Ervi Afifah $^{3}$, Seila Arumwardana ${ }^{3}$, Hanna Sari Widya Kusuma ${ }^{3}$, Rizal $^{3}$, Wahyu Widowati ${ }^{4, *}$ \\ ${ }^{1}$ Health Polytechnic of Bandung, Jl. Babakan Loa Cimahi Utara, Bandung 40514, Indonesia \\ ${ }^{2}$ Health Polytechnic of Banten, Jl. Dr. Sitanala, Karangsari, Tangerang, Banten 15121, Indonesia \\ ${ }^{3}$ Biomolecular and Biomedical Research Center, Aretha Medika Utama, Bandung 40163, Indonesia \\ ${ }^{4}$ Medical Research Center, Faculty of Medicine, Maranatha Christian University, Bandung 40164, Indonesia \\ *Corresponding author. E-mail: wahyu_w60@yahoo.com
}

Received date: Feb 28, 2018; Revised date: Jul 5, 2018; Accepted date: Jul 12, 2018

\section{Abstract}

ACKGROUND: Oxidative stress is closely related to all aspects of cancer. Cosmos caudatus ethanolic extract (CCEE) has been proved to have antioxidant effect that inhibited cancer cell growth due to its bioactive compounds such as catechin, quercetin and chlorogenic acid. This study aimed to evaluate antioxidant and anticancer activity of CCEE and its compounds.

METHODS: Total phenol was measured according to the Folin-Ciocalteu method. Catechin, quercetin and chlorogenic acid contained in CCEE were identified by high-performance liquid chromatography (HPLC). Antioxidant activity was evaluated by $2,2^{\prime}$-azino-bis-(3ethylbenzthiazoline-6-sulfonic acid) (ABTS)-reducing activity, 1,1-diphenyl-2-picrylhydrazyl (DPPH) scavenging activity, and ferric reducing antioxidant power (FRAP) activity test. The cytotoxic activity of CCEE was determined by MTS [3-(4,5-dimethylthiazol-2-yl)-5-(3-carboxymethoxyphenyl)-2-(4-sulfophenyl)-2H-tetrazolium] assay on HeLa cells.
RESULTS: The result showed that total phenol of CCEE was $181.64 \pm 0.93 \mu \mathrm{g}$ Cathecin/mg extract. ABTSreducing activity test showed that catechin had the highest activity $(2.90 \pm 0.04 \mu \mathrm{g} / \mathrm{mL})$, while CCEE had moderate activity compared to other compounds. FRAP activity test demonstrated that catechin had the highest activity (315.83 $\mu \mathrm{M} \mathrm{Fe}(\mathrm{II}) / \mu \mathrm{g}$ ) compared to other compounds. DPPH scavenging activity of CCEE was $22.82 \pm 0.05 \mu \mathrm{g} / \mathrm{mL}$. Cytotoxicity test on HeLa cell showed that CCEE had lower activity (inhibitory concentration (IC) $50=89.90 \pm 1.30$ $\mu \mathrm{g} / \mathrm{mL})$ compared to quercetin $\left(\mathrm{IC}_{50}=13.30 \pm 0.64 \mu \mathrm{g} /\right.$ $\mathrm{mL})$.

CONCLUSION: CCEE has the lowest antioxidant activity compared to quercetin, catechin, and chlorogenic acid and has the lowest anticancer activity compared to quercetin. However, CCEE and its compounds has potential as antioxidant and anticancer properties.

KEYWORDS: antioxidant, anticancer, catechin, Cosmos caudatus, quercetin

Indones Biomed J. 2018; 10(3): 243-9

\section{Introduction}

Initiation, promotion and progression are the three multistage of cancer.(1,2) Oxidative stress is related to the cancer initiation and progression by increasing DNA mutations or inducing DNA damage, genome instability and cell proliferation.(3) Wide spectrum of diseases, such as most type of cancer, are involving the role of reactive oxygen species (ROS).(4) Imbalance between production of free radicals and reactive metabolites called oxidants or ROS are the sign of oxidative stress, leading to damage of important biomolecules and cells which potentially affected on the whole organism.(5) 
Cosmos caudatus locally known as 'Ulam raja' and widely used as traditional medicine in Southeast Asia, is a herb of the family Compositae. Some studies reported that C. caudatus contains some bioactive compounds such as ascorbic acid, quercetin, chlorogenic acid and catechin. These natural compounds have been reported to be excellent antioxidants.(6-8) C. caudatus is suggested to have high antioxidant capacity, antidiabetic activity, antihypertensive properties, anti-inflammatory responses, bone protective effect, antimicrobial activity and anticancer properties. $(9,10)$ This research aimed to evaluate the antioxidant potency and cytotoxic effect of $C$. caudatus ethanol extracts. Therefore, we also used high performance liquid chromatography (HPLC) method to observe the compounds in the C. caudatus extracts based on standard compound.(11)

\section{Methods}

\section{Plant Extract Preparation}

Leaves of C. caudatus were collected from Cihideung, Lembang, West Java, Indonesia. The plants were identified by herbarium staff, Department of Biology, School of Life Science and Technology, Bandung Institute of Technology, Bandung, West Java, Indonesia. The C. caudatus simplicia $(300 \mathrm{~g})$ was extracted with ethanol $70 \%$ using maceration technique. Ethanol filtrate was filtered, and waste was remacerated in triplicate. Using RV 10 rotary evaporator (IKA Works, Wilmington, NC, USA) at $50^{\circ} \mathrm{C}$, the filtrate was concentrated to obtain extract. The extract was stored at $-20^{\circ} \mathrm{C} .(12-14)$

\section{HPLC Assay}

C. caudatus ethanolic extract (CCEE) chemical profiling analysis was performed using HPLC. Quantification of CCEE was done using the standard chlorogenic acid (Chengdu Biopurify Phytochemical, Sichuan, China), catechin (Sigma Aldrich, Darmstadt, Germany) and quercetin (Sigma Aldrich). HPLC analysis used the Hitachi Pump HPLC L-6200, Hitachi L-4000 UV detector and Reverse Phase Column C-18 (Phenosphere ODS-2, Phenomenex, $4.6 \mathrm{~mm}$ x $250 \mathrm{~mm}$ ). Acetonitrile 70\% (Merck, Darmstadt, Germany) was used as mobile phase (isocratic) with flow rate of $1.0 \mathrm{~mL} / \mathrm{min}$. The samples were then dissolved in methanol $70 \%(1 \mathrm{mg} / \mathrm{mL})$, filtered through a $0.22 \mu \mathrm{m}$ syringe, and injected $(20 \mu \mathrm{L})$ to the column. UV absorbance was measured at $254 \mathrm{~nm}$.(11)

\section{Total Phenolic Content Assay}

Total phenolic content was measured according to the FolinCiocalteu method. Briefly $15 \mu \mathrm{L}$ of samples was placed into microplate then added $75 \mu \mathrm{L}$ of Folin-Ciocalteu's reagent $2.0 \mathrm{M}$ (Merck), followed by $60 \mu \mathrm{L}$ of sodium carbonate $7.5 \%$ (Merck). The mixture was incubated at $45^{\circ} \mathrm{C}$ for 15 minutes.(15,16) Subsequently, absorbance value was measured at $760 \mathrm{~nm}$ using microplate reader (Multiskan ${ }^{\mathrm{TM}}$ GO Microplate Spectrophotometer, Thermo Scientific, Waltham, MA, USA). Total phenolic content expressed as catechin equivalent was calculated by the following formula:

$$
\mathrm{C}=\frac{\mathrm{c} \mathrm{x} \mathrm{v}}{\mathrm{m}}
$$

C: total content of phenolic compounds ( $\mu \mathrm{g} / \mathrm{mg}$ ) of $C$. caudatus in catechin equivalent;

c: the concentration of catechin established from the calibration curve $(\mu \mathrm{g} / \mathrm{mL})$;

$\mathrm{V}$ : the volume of extract $(\mathrm{mL})$; $\mathrm{m}$ : the weight of extract (mg).

2,2'-Azino-bis-(3-ethylbenzthiazoline-6-sulfonic acid) (ABTS)-reducing Activity Assay

$\mathrm{ABTS}^{+}$solution was produced by reacting $14 \mathrm{mM} \mathrm{ABTS}$ and $4.9 \mathrm{mM}$ potassium persulfate (Merck) (1:1 volume ratio) for 16 hours in dark condition at room temperature. The mixture was then diluted with $5.5 \mathrm{mM}$ PBS (pH 7.4) until the absorbance of the solution was $0.70 \pm 0.02$ at wavelength $745 \mathrm{~nm}$. In brief, $2 \mu \mathrm{L}$ of various concentrations of sample $(0.23,0.47,0.94,1.88,3.75,7.50,15.00 \mu \mathrm{g} / \mathrm{mL}$; $\mu \mathrm{M})$ was added to each well at 96-well microplate, then the fresh $198 \mu \mathrm{L} \mathrm{ABTS}^{+}$solution (Sigma Aldrich) was added. Then, the plate was incubated for 6 minutes at $30^{\circ} \mathrm{C}$ and calculated its absorbance at $745 \mathrm{~nm}$. The ratio of reducing $\mathrm{ABTS}^{+}$absorbance in the presence of the sample relative to the absorbance in the absence of the sample (negative control) was determined as the inhibition percentage of ABTS radical (\%). The calculation of the median Inhibitory Concentration (IC) $)_{50}$ was also measured. $(14,16,17)$

\section{Ferric Reducing Antioxidant Power (FRAP) Assay}

The FRAP reagent was prepared by mixing acetate buffer $(10 \mathrm{~mL}) 300 \mathrm{mM}$, ferric chloride hexahydrate (Merck) (1 mL) $20 \mathrm{mM}$ dissolved in distilled water, and $1 \mathrm{~mL}$ of 2,4,6-Tris(2-pyridyl)-s-triazine (TPTZ) (Sigma Aldrich) 10 $\mathrm{mM}$ dissolved in $\mathrm{HCl} 40 \mathrm{mM}$. In 96-well microplate, $7.5 \mu \mathrm{L}$ of various concentrations of sample $(1.17,2.34,4.69,9.38$, 
18.75, 37.50, $75.00 \mu \mathrm{g} / \mathrm{mL} ; \mu \mathrm{M})$ was mixed with $142.5 \mu \mathrm{L}$ FRAP reagent, and incubated at $37^{\circ} \mathrm{C}$ for 30 minutes. The absorbance value was measured at $593 \mathrm{~nm}$ with Multiskan ${ }^{\mathrm{TM}}$ GO Microplate Spectrophotometer (Thermo Scientific). The standard curve was created using $\mathrm{FeSO}_{4}$, between 0.019 and $95 \mu \mathrm{g} / \mathrm{mL} \mathrm{FeSO}_{4}$. The measurement results were expressed in $\mu \mathrm{M} \mathrm{Fe}(\mathrm{II}) / \mu \mathrm{g}$ extract. $(14,16,18)$

\section{2,2-Diphenyl-1-picrylhydrazil (DPPH) Scavenging Assay}

The DPPH scavenging assay was used to measure the radical scavenging activity of the samples.(14) Samples (50 $\mu \mathrm{L})$ with various concentrations were added to each well in a 96-well microplate. It was followed by addition of 200 $\mu \mathrm{L}$ of DPPH (Sigma Aldrich) solution $(0.077 \mathrm{mmol} / \mathrm{L}$ in methanol) into the well. The mixture was then incubated in the dark for 30 minutes at room temperature. The absorbance was read using a microplate reader at $517 \mathrm{~nm}$ wavelength. The radical scavenging activity was measured using the following formula:

$$
\% \text { Scavenging }=(\text { Ac }- \text { As }) / \text { Ac } \times 100
$$

$\mathrm{Ac}=$ negative control absorbance (without sample).

As $=$ sample absorbance.

\section{Cytotoxicity Assay}

The cervical cancer cells (HeLa' (American Type Culture Collection (ATCC) CC-Chemokine Ligand 2 (CCL2)) were obtained from Stem Cell and Cancer Institute, Jakarta, Indonesia. The cells were maintained in Dulbecco modified Eagle's medium containing 10\% FBS (Invitrogen, California, USA), $100 \mathrm{U} / \mathrm{mL}$ penicillin (Invitrogen) and $100 \mathrm{mg} / \mathrm{mL}$ streptomycin (Invitrogen). Then, the cells were incubated at $37^{\circ} \mathrm{C}, 5 \% \mathrm{CO}_{2}$.(12) Briefly, $5 \times 10^{3}$ of cells were seeded in 96 well-plates for 24 hours.(12,13) The medium was discarded, then $180 \mu \mathrm{L}$ of fresh medium was added into each well. The cells were treated with $20 \mu \mathrm{L}$ of $C$. caudatus ethanol extract in various concentrations $(1000,500,250$, $125,62.5,31.25,16.125 \mu \mathrm{g} / \mathrm{mL})$ and quercetin in various concentrations $(200,100,50,25,12.5,6.25,3.125 \mu \mathrm{M})$. Dimethyl sulfoxide (DMSO) 10\% was added in different well as blank. All samples and blank were set in triplicate and incubated for 24 hours. Untreated cells were employed as control. The 3-(4,5-dimethylthiazol-2-yl)-5-(3-carboxymethoxyphenyl)-2-(4-sulfophenyl)-2H-tetrazolium

(MTS) assay (Promega, Madison,WI, USA) was used to determine cell viability.(12) Twenty $\mu \mathrm{L}$ MTS was added to each well. The plate was incubated in $5 \% \mathrm{CO}_{2}$ at $37^{\circ} \mathrm{C}$ for 4 hours.
The absorbance was measured at $490 \mathrm{~nm}$ with a microplate reader. The data were then presented as percentage of viable cells $(\%) .(12,13)$

\section{Results}

\section{Total Phenolic Content}

Total phenolic content of the sample was measured, this study show that CCEE has total phenolic content is $181.64 \pm 0.93 \mu \mathrm{g}$ Cathecin/mg extract.

\section{HPLC Assay}

The compounds content of CCEE was evaluated using HPLC with quercetin, catechin and chlorogenic acid as standard. Figure 1 shows that quercetin, catechin, and chlorogenic acid had retention time at 1.64 minutes, 1.40 minutes and 1.30 minutes, respectively. CCEE has peak at 1.403 minutes, it is close with catechin peak (1.40 minutes) which was assumed as catechin. This HPLC assay indicated that CCEE contained catechin compound.

\section{ABTS-reducing Activity}

ABTS-reducing activity of CCEE, catechin, quercetin and chlorogenic acid can be seen in Figure 2A and Table 1. Figure 2A shows ABTS-reducing activity in concentrationdependent manner, where higher concentration of sample increased ABTS-reducing activity. At the highest concentration of sample $(15 \mu \mathrm{g} / \mathrm{mL})$, catechin has the highest percentage of ABTS-reducing activity (73.53\%) compared to quercetin $(62.10 \%)$, CCEE (24.94\%) and chlorogenic acid $(22.46 \%)$. This results indicated that CCEE had low ABTS-reducing activity among other compounds except chlorogenic acid.

Table 1. IC $_{50}$ value of ABTS-reducing activity of CEE, catechin, quercetin and chlorogenic acid.

\begin{tabular}{lcc}
\hline \multirow{2}{*}{ Sample } & \multicolumn{2}{c}{ ABTS-reducing Activity } \\
\cline { 2 - 3 } & IC $_{\mathbf{5 0}}(\boldsymbol{\mu M})$ & IC $_{\mathbf{5 0}}(\boldsymbol{\mu g} / \mathbf{m L})$ \\
\hline CCEE & - & $31.97 \pm 1.42$ \\
Catechin & $10.00 \pm 0.15$ & $2.90 \pm 0.04$ \\
Quercetin & $12.04 \pm 0.16$ & $3.64 \pm 0.05$ \\
Chlorogenic Acid & $35.94 \pm 2.14$ & $12.70 \pm 0.76$ \\
\hline
\end{tabular}

${ }^{*} \mathrm{CCEE}=C$. caudatus ethanolic extract, $\mathrm{ABTS}=2,2$ '-azino-bis(3-ethylbenzthiazoline-6-sulfonic acid). The data was presented as mean \pm standard deviation. The ABTS-reducing activity assay was measured in triplicate for each sample. 
A

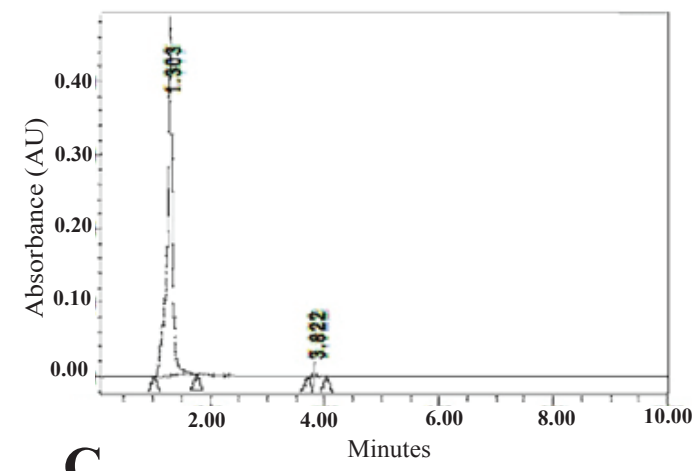

C

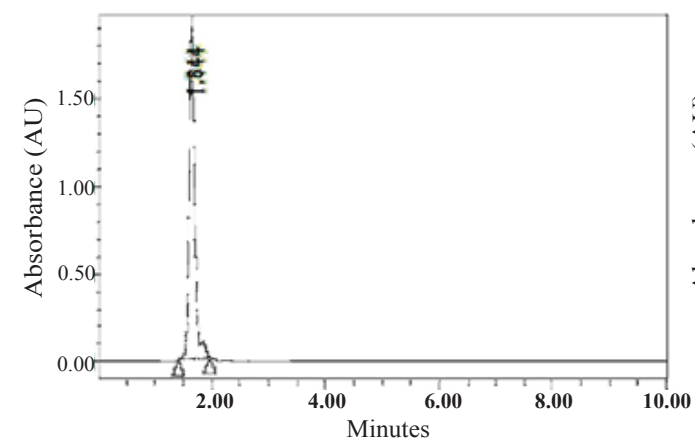

B

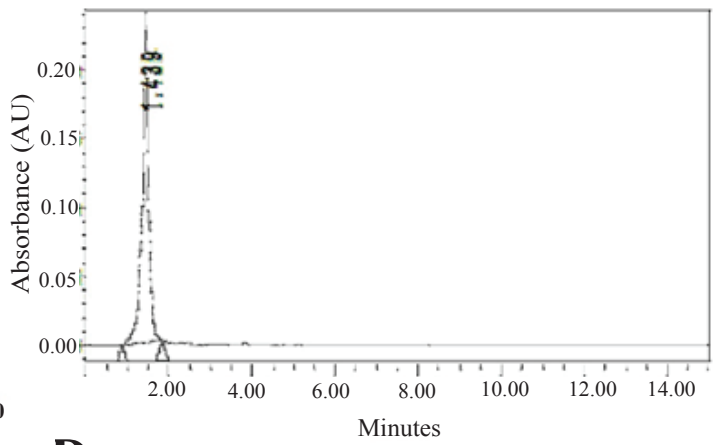

D

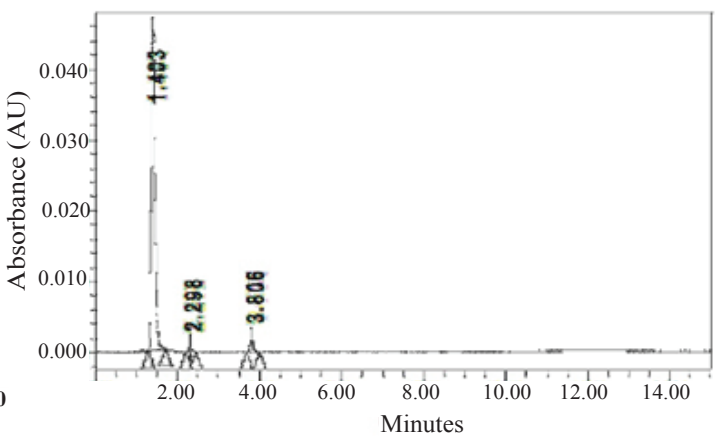

Figure 1. Chromatogram of extract and compounds with HPLC. A: Chlorogenic acid; B: Catechin; C: Quercetin; D: CCEE . *CCEE $=C$. caudatus ethanolic extract, HPLC $=$ High-Performance Liquid Chromatography. This research was conducted in triplicate for each treatment.

Table 1 shows that catechin had the lowest $\mathrm{IC}_{50}$ value $(2.90 \pm 0.04 \mu \mathrm{g} / \mathrm{mL})$ compared to quercetin $(3.64 \pm 0.05 \mu \mathrm{g} /$ $\mathrm{mL})$, chlorogenic acid $(12.70 \pm 0.76 \mu \mathrm{g} / \mathrm{mL})$, and CCEE $(31.97 \pm 1.42 \mu \mathrm{g} / \mathrm{mL})$. This finding supported the result of ABTS-reducing activity demonstrated the lowest activity of CCEE compared to other samples.

\section{FRAP Activity}

FRAP activity of CCEE, catechin, quercetin and chlorogenic acid can be seen in Figure 2B. The antioxidant activity of CCEE, catechin, quercetin and chlorogenic acid were evaluated using FRAP activity assay. Catechin had the highest activity $(315.83 \mu \mathrm{M} \mathrm{Fe}(\mathrm{II}) / \mu \mathrm{g})$ compared to
A

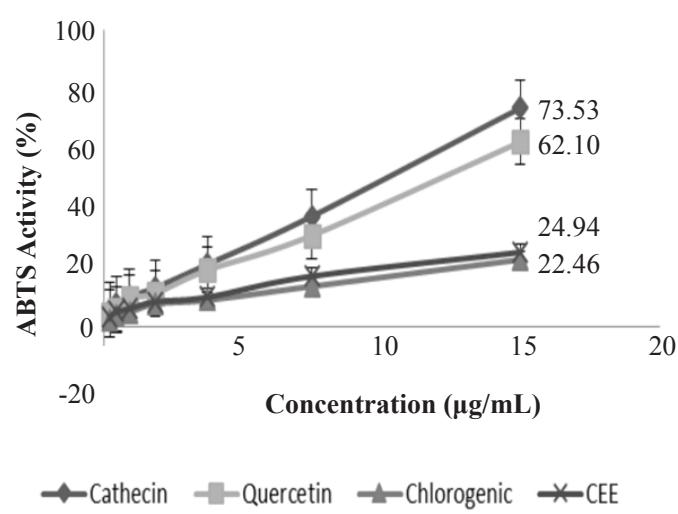

B

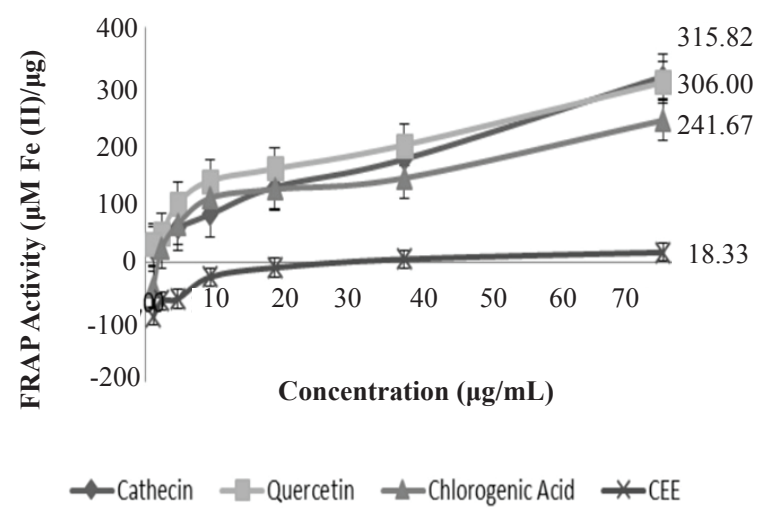

Figure 2. ABTS and FRAP activity of CCEE, catechin, quercetin and chlorogenic acid. *CCEE = C. caudatus ethanolic extract, ABTS = 2,2'-azino-bis-(3-ethylbenzthiazoline-6-sulfonic acid), FRAP = Ferric Reducing Antioxidant Power. This research was conducted in triplicate for each treatment. CCEE, catechin, quercetin and chlorogenic acid in ABTS assay were diluted in DMSO to reach the final concentration of $0.23 ; 0.47 ; 0.94 ; 1.88 ; 3.75 ; 7.50 ; 15.00(\mu \mathrm{g} / \mathrm{mL}$ for CEE and $\mu \mathrm{M}$ for compounds), while in FRAP assay were diluted in DMSO to reach the final concentration of $1.17 ; 2.34 ; 4.69 ; 9.38 ; 18.75 ; 37.50 ; 75.00(\mu \mathrm{g} / \mathrm{mL}$ for CCEE and $\mu \mathrm{M}$ for compounds). 
quercetin $(306.00 \mu \mathrm{M} \mathrm{Fe}(\mathrm{II}) / \mu \mathrm{g})$, chlorogenic acid (241.67 $\mu \mathrm{M} \mathrm{Fe}(\mathrm{II}) / \mu \mathrm{g})$ and $\mathrm{CCEE}(18.33 \mu \mathrm{M} \mathrm{Fe}(\mathrm{II}) / \mu \mathrm{g})$. This indicated that CCEE had the lowest antioxidant activity compared to other compounds (Figure 2B).

\section{DPPH Scavenging Activity}

The median $\mathrm{IC}_{50}$ of DPPH scavenging activity of CCEE, catechin, quercetin and chlorogenic acid can be seen in Table 1. It shows that the $\mathrm{IC}_{50}$ value of $\mathrm{DPPH}$ scavenging activity of CCEE $(22.82 \pm 0.05 \mu \mathrm{g} / \mathrm{mL})$ indicated antioxidant activity through scavenging DPPH free radical.

\section{Cytotoxic Activity}

Figure 3 shows the correlation between CCEE and quercetin concentration and its cytotoxicity on HeLa cell. Viability of cells decreased in concentration-dependent manner. The increased concentration was correlated with increased toxicity ( $<90 \%$ viable cells). The highest extract concentration $(1000.00 \mu \mathrm{g} / \mathrm{mL}$ and $200.00 \mu \mathrm{M})$ demonstrated the lowest of viability of cells by CCEE was $19.23 \%$ and quercetin $34.07 \%$, respectively. CCEE and quercetin can inhibit the growth of HeLa cancer cell line with minimum inhibitory concentration $\left(\mathrm{IC}_{50}\right)$ values $89.90 \pm 1.30 \mu \mathrm{g} / \mathrm{mL}$ and $43.99 \pm 2.15 \mu \mathrm{M}(13.30 \pm 0.64 \mu \mathrm{g} /$ $\mathrm{mL}$ ), respectively (Table 2). This indicated that CCEE had lower cytotoxicity compared to quercetin.

\section{Discussion}

C. caudatus has been known as a potential herb that has antioxidant and anticancer activity.(19) C. caudatus has

\section{A}

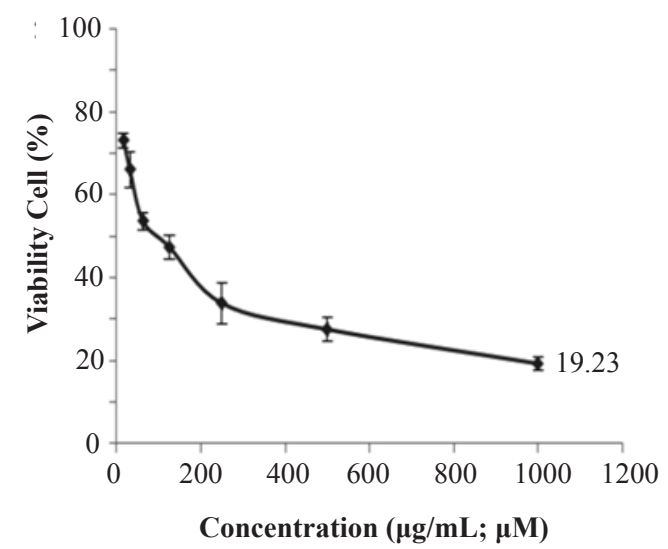

Table 2. $\mathrm{IC}_{50}$ value cytotoxicity HeLa cells of $\mathrm{CCEE}$ and quercetin.

\begin{tabular}{lcc}
\hline \multirow{2}{*}{ Sample } & \multicolumn{2}{c}{ Cytotoxic Activity } \\
\cline { 2 - 3 } & $\mathbf{I C}_{\mathbf{5 0}}(\boldsymbol{\mu M})$ & $\mathbf{I C}_{\mathbf{5 0}}(\boldsymbol{\mu g} / \mathbf{m L})$ \\
\hline CCEE & - & $89.90 \pm 1.30$ \\
Quercetin & $43.99 \pm 2.15$ & $13.30 \pm 0.64$ \\
\hline
\end{tabular}

$* \mathrm{CCEE}=C$. caudatus ethanolic extract. $\mathrm{IC}_{50}$ of $\mathrm{CCEE}$ and quercetin was presented as $\mu \mathrm{g} / \mathrm{mL}$ and $\mu \mathrm{M}$, respectively. The data was presented as mean \pm standard deviation. This research was conducted in triplicate for each treatment.

been reported to have high antioxidant capacity, mainly due to its polyphenol content.(7) The rich-phenolic foods are the sources of natural antioxidants. $(19,20)$ The total phenolic content of CCEE in this study was $181.64 \mu \mathrm{g}$ Cathecin/mg extract. The result of other study showed that $C$. caudatus has high total phenolic content $(1274 \pm 98 \mathrm{GAE} \mathrm{mg} / 100 \mathrm{~g}$ fresh weight) in the acetone/water system.(7) The aqueous extract of $C$. caudatus has also been known to have the highest phenolic content.(21) Other study showed that the total phenolic content of $C$. caudatus ethanol extract (1144.6 $\mathrm{mg} / 100 \mathrm{~g}$ ) was higher than C. caudatus water solvent $(844.8$ mg/100g).(22) High phytochemical contents, antioxidants, proteins, amino acids, vitamins and minerals are associated with risk reduction of free radical-related degenerative diseases.(23)

In this study, HPLC analysis was evaluated to determine compounds content of C. caudatus. Quercetin, catechin and chlorogenic acid were used as standards. Figure 1 shows that CCEE peaked at 1.403 minutes which was assumed as catechin. This indicated CCEE contain catechin compound.

B

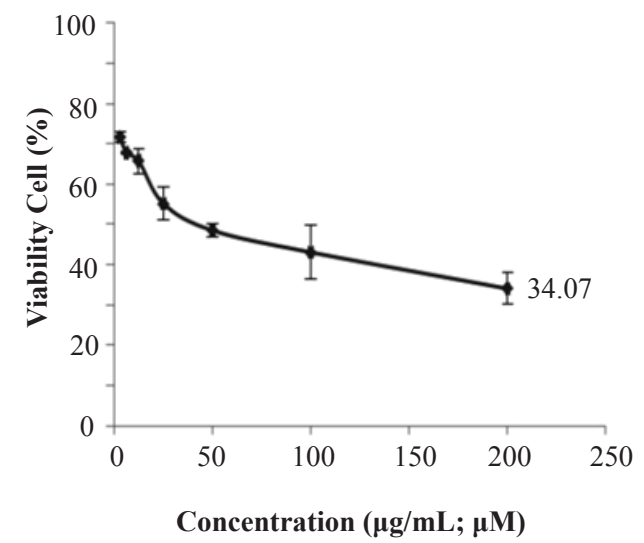

Figure 3. Viability of HeLa cell of CEE and quercetin. A: CEE; B: Quercetin. ${ }^{*} \mathrm{CCEE}=C$. caudatus ethanolic extract. This research was conducted in triplicate for each treatment. CCEE was diluted in DMSO to reach the final concentration of $16.125 ; 31.25 ; 62.50 ; 125.00$; $250.00 ; 500.00 ; 1000.00(\mu \mathrm{g} / \mathrm{mL})$; Quercetin was diluted in DMSO to reach the final concentration of 3.125; 6.25; 62.50; 12.50; 25.00; $50.00 ; 100.00200 .00(\mu \mathrm{M})$. 
Based on Noriham, et al., study, C. caudatus ethanol extract measured by HPLC show presence of catechin.(24)

ABTS-reducing activity of CCEE had moderate activity compared to catechin, quercetin and chlorogenic acid. Based on the result above, CCEE had moderate activity compared to catechin, quercetin and chlorogenic acid, meanwhile in previous study, CCEE had the highest ABTSreducing activity compared to other plants $(4.71 \mu \mathrm{mol} \mathrm{TE} / \mathrm{g}$ fw).(25) High antioxidants activity of $C$. caudatus was associated with the ability to reduce oxidative stress.(7) Another study also proved that $C$. caudatus had extremely high antioxidant compared to other plants through total antioxidant capacity (ascorbic acid equivalent antioxidant capacity (AEAC) value).(10)

In this research, DPPH scavenging activity of CCEE $\left(\mathrm{IC}_{50}=22.82 \mu \mathrm{g} / \mathrm{mL}\right)$, indicated that antioxidant activity through DPPH free radical scavenging activity. In our previous studies, the $\mathrm{IC}_{50} \mathrm{DPPH}$ scavenging activity values of catechin were $7.02 \mu \mathrm{g} / \mathrm{mL}$ (26) and $8.11 \mu \mathrm{M}$ (27), while DPPH values of quercetin were $4.279 \mu \mathrm{g} / \mathrm{mL}$ (28), $3.244 \mu \mathrm{g} /$ $\mathrm{mL}(29)$ and $19.200 \mu \mathrm{g} / \mathrm{mL}$ (21). The FRAP activity value of CCEE was the lowest among other compounds. Some studies reported that $C$. caudatus had greater antioxidant activity than Sauropus androgynus (L) Merr and Centella asiatica in DPPH and FRAP assays.(30) Other study showed that $C$. caudatus had the greatest FRAP activity among other plants (25), also CCEE had the highest DPPH scavenging activity which was correlated with flavonoid content in the plants. C. caudatus had been reported to possess the highest flavonoid and phenolic content.(25) C. caudatus aqueous extract is a good source of antioxidant because it has the highest DPPH and FRAP values.(10) In another study, $C$. caudatus had the highest free radical scavenging potential extract (86.85\%).(31) CCEE also showed beneficial activities in reducing number of parameters such as peroxyl value as an antioxidant. Phenolic content in CCEE plays a key role in scavenging free radicals which cause oxidative stress.(19) In addition, phenolic compounds have been shown to possess antioxidant ability which facilitates scavenging electrophiles and active oxygen species, slows down nitrosation and chelates metal ions to limit autooxidation, and increases the ability to adjust some enzyme actions. $(32,33)$

Tumorigenesis occurs due to the increasing free radicals that lead to DNA damage and mutation, apoptosis inhibition, cell cycle/proliferation stimulation, and DNA repair inhibition.(34) The role of ROS in cancer development can be determined in three different stages. Firstly, generating DNA damage including mutations and structural alterations is the ROS first role, followed by the second stage which is the promotion stage where ROS blocks cell-cell communication leading to abnormal gene expression and modification of second messenger, resulting in increased cell proliferation or decreased cell apoptosis. Last stage, furthermore, is the progression of cancer caused by oxidative stress affecting further DNA alterations.(1) Free radicals can react with membrane fatty acids and form lipid peroxides, accumulation of which leads to production of carcinogenic agents.(35) In this study, CCEE had lower cytotoxicity on HeLa cell compared to quercetin. These results were confirmed by Lee and Vairappan that found a weak cytotoxic activity of the ethanolic extract of $C$. caudatus against P388 murine leukemia cells.(9) However, in other study, C. caudatus exhibited the highest DPPH free radical scavenging, ABTS-reducing activity, FRAP and inhibition of linoleic acid.(24)

\section{Conclusion}

C. caudatus and its compounds showed antioxidant activities as measured through ABTS-reducing activity, DPPH scavenging activity, and FRAP activity. CCEE has the lowest antioxidant activity compared to quercetin, catechin and chlorogenic acid. CCEE also has the lowest cytotoxic activity compared to quercetin. However, CCEE and its compounds has potential as antioxidant and anticancer properties.

\section{Acknowledgment}

This study was supported by the Grants-in-Aid from Penelitian Unggulan, Riset Pembinaan Tenaga Kesehatan (2017), Ministry of Health, Republic of Indonesia. The author also thankful to Annisa Amalia, Yukko Arinta, Fajar Sukma Perdana, Ni Luh Wisma Ekayanti, Annisa Arlisyah, and Rismawati Laila from Biomolecular and Biomedical Research Center, Aretha Medika Utama, Bandung, Indonesia for their valuable assistance.

\section{References}

1. Arnes B, Gold L. Animal cancer tests and cancer prevention. J Natl Cancer Inst Monogr. 1992; 2014: 125-32.

2. Guyton K, Kensler T. Oxidative mechanisms in carcinogenesis. $\mathrm{Br}$ Med Bull. 1993; 49: 523-44. 
3. Visconti R, Grieco D. New insights on oxidative stress in cancer. Curr Opin Drug Discov Devel. 2009; 12: 240-5.

4. Reuter S, Gupta S, Chaturvedi M, Aggarwal B. Oxidative stress, inflammation, and cancer: how are they linked? Free Radic Biol Med. 2010; 49: 1603-16.

5. Durackova Z. Some current insights into oxidative stress. Physiol Res. 2010; 59: 459-69.

6. Abas F, Shaari K, Lajis N, Israf D, Kalsom Y. Antioxidative and radical scavenging properties of the constituents isolated from Cosmos caudatus Kunth. Nat Prod Res. 2003; 9: 245-58.

7. Shui G, Leong L, Wong S. Rapid screening and characterisation of antioxidants of Cosmos caudatus using liquid chromatography coupled with mass spectrometry. J Chromatogr B Analyt Technol Biomed Life Sci. 2005; 827: 127-38.

8. Mustafa R, Abdul H, Mohamed S, Bakar F. Total phenolic compounds, flavonoids, and radical scavenging activity of 21 selected tropical plants. J Food Sci. 2010; 75: C28-35.

9. Lee T, Vairappan C. Antioxidant, antibacterial and cytotoxic activities of essential oils and ethanol extracts of selected south east asian herbs. J Med Plant Res. 2011; 5: 5284-90.

10. Cheng SH, Barakatun-Nisak M, Anthony J, Ismail A. Potential medicinal benefits of Cosmos caudatus (Ulam Raja): a scoping review. J Res Med Sci. 2015; 20: 1000-06.

11. Widowati W, Darsono L, Suherman J, Yellianty Y, Maesaroh M. High performance liquid chromatography (HPLC) analysis, antioxidant, antiaggregation of mangosteen peel extract (Garcinia mangostana L.). Int J Biosci Biochem Bioinformatic. 2014; 4: 458-66.

12. Widowati W, Mozef T, Risdian C, Yellianty Y. Anticancer and free radical scavenging potency of Catharanthus roseus, Dendrophthoe petandra, Piper betle and Curcuma mangga extracts in breast cancer cell lines. Oxidant Antioxid Med Sci. 2013; 2: 137-42.

13. Widowati W, Wijaya L, Wargasetia T, Bachtiar I, Yellianty Y, Laksmitawati D. Antioxidant, anticancer and apoptosis-inducing effects of Piper extracts in HeLa cells. J Exp Integr Med. 2013; 3: 225-30.

14. Widowati W, Fauziah N, Herdiman H, Afni M, Afifah E, Kusuma H, et al. Antioxidant and anti aging assays of Oryza sativa extracts, vanillin and coumaric acid. J Nat Remed. 2016; 16: 88-99.

15. Ivanova D, Gerova D, Chervenkov T, Yankova T. Polyphenols and antioxidant capacity of Bulgarian medicinal plants. J Ethnopharmacol. 2005; 96: 145-150.

16. Widowati W, Widyanto R, Husin W, Ratnawati H, Laksmitawati D, Setiawan B, et al. Green tea extract protects endothelial progenitor cells from oxidative insult through reduction of intracellular reactive oxygen species activity. Iran J Basic Med Sci. 2014; 17: 702-09.

17. Etoundi C, Kuat D, Ngondi J, Oben J. Anti-amylase antilipase and antioxidant effects of aqueous extracts of some cameroonian spices. J Nat Products. 2010; 3: 165-71.

18. Mishra A, Bapat M, Tilak J, Devasagayam T. Antioxidant activity of Garcinia indica (kokam) and its syrup. Curr Sci. 2006; 91: 90-3.

19. Mediani A, Abas F, Khatib A, Tan C. Cosmos caudatus as a potential source of polyphenolic compounds: optimisation of oven drying conditions and characterisation of its functional properties. Molecule. 2013; 18: 10452-64.

20. Dai J, Mumper R. Plant phenolics: extraction, analysis and their antioxidant and anti-cancer properties. Molecule. 2010; 15: 7313-52.

21. Sumazian Y, Syahida A, Hakiman M, Maziah M. Anti-oxidant activities, flavonoids, ascorbic acid and phenolic contents of Malaysian vegetables. J Med Plants Res. 2010; 4: 881-90.

22. Shui G, Leong LP, Wong SP. Rapid screening and characterisation of antioxidants of Cosmos caudatus using liquid chromatography coupled with mass spectrometry. J Chromatogr B. 2005; 827: 127 38.

23. Moshawih S, Cheema M, Ahmad Z, Zakaria Z, Hakim M. A comprehensive review on Cosmos caudatus (Ulam raja): pharmacology, ethnopharmacology, and phytochemistry. Int Res J Edu Sci. 2017; 1: 14-31.

24. Noriham A, Dian-Nashiela F, Kherni Hafifi B, Nooraain H, Azizah A Influences of maturity stages and extraction solvents on antioxidant activity of Cosmos caudatus leaves. Int J Res Studies Biosci. 2015; 3: $1-10$.

25. Andarwulan N, Batari R, Sandrasari D, Bolling B, Wijaya H. Flavonoid content and anti-oxidant activity of vegetables from Indonesia. Food Chem. 2010; 121: 1231-35.

26. Budiman I, Tjokropranoto R, Widowati W, Rahardja F, Maesaroh M, Fauziah N. Antioxidant and anti-malarial properties of catechins. Br J Med Med Res. 2015; 5: 895-02.

27. Evacuasiany E, Ratnawati H, Liana L, Widowati W, Maesaroh M, Mozef T, et al. Cytotoxic and antioxidant activities of catechins in inhibiting the malignancy of breast cancer. Oxid Antioxid Med Sci. 2014; 3: 141-46.

28. Widowati W, Ratnawati H, Husin W, Maesaroh M. Antioxidant properties of spice extracts. Biomed Eng. 2015; 1: 24-9.

29. Widowati W, Mozef T, Risdian C, Ratnawati H, Tjahjani S, Sandra F. The comparison of antioxidative and proliferation inhibitor properties of Piper betle L., Catharanthus roseus [L] G.Don, Dendrophtoe petandra L., Curcuma mangga Val. extracts on T47D cancer cell line. Int Res J Biochem Bioinformatic. 2011; 1: 22-8.

30. Wong S, Leong L, Koh J. Antioxidant activities of aqueous extracts of selected plants. Food Chem. 2006; 99: 775-83.

31. Rafat A, Philip K, Muniandy S. Antioxidant potential and phenolic content of selected Malaysian plants. Res J Biotech. 2010; 5: 16-19.

32. Lim Y, Murtijaya J. Antioxidant properties of Phyllanthus amarus extracts as affected by different drying methods. LWT Food Sci Technol. 2007; 40: 1664-9.

33. Madsen H, Bertelsen G. Spices as antioxidants. Trends Food Sci Technol. 1995; 6: 271-7.

34. Hussain S, Hofseth L, Harris C. Radical causes of cancer. Nat Rev Cancer. 2003; 3: 276-86

35. Khansari N, Shakiba Y, Mahmoudi M. Chronic inflammation and oxidative stress as a major cause of age-related diseases and cancer. Recent Pat Inflamm Allergy Drug Discov. 2009; 3: 73-80. 